\title{
FIRE BEHAVIOR VARIABLES AND HAZARD INDICES OF FOREST FIRES ${ }^{1}$
}

\author{
Fillipe Tamiozzo Pereira Torres ${ }^{2 *}$, Gumercindo Souza Lima ${ }^{2}$ and Bráulio Furtado Alvares ${ }^{3}$
}

\footnotetext{
${ }^{1}$ Received on 18.04.2018 accepted for publication on 11.06.2018.

${ }^{2}$ Universidade Federal de Viçosa, Departamento de Engenharia Florestal, Viçosa, MG-Brasil. E-mail: <torresftp2@gmail.com> and $<$ gslima@ufv.br>.

${ }^{3}$ Secretaria de Estado de Meio Ambiente e Desenvolvimento Sustentável, Ubá, MG-Brasil. E-mail: <brauliofa@hotmail.com>. *Corresponding author.
}

\begin{abstract}
The objective of this study was to evaluate the performance of different fire hazard indices (FWI, FMA, FMA+, Telicyn, Nesterov, P-EVAP and EVAP/P), taking into account the fire behavior variables and the susceptibility to fire expressed by the moisture of the combustible material. For this purpose, controlled burnings were performed at different times and information was recorded in relation to the meteorological conditions, characteristics of the combustible material and fire behavior variables. In general, all the indices presented significant correlations with both the moisture of the combustible material and the behavior of the fire. However, in general, a higher linear correlation of components of the Canadian Fire Weather Index (FWI) system was observed in predicting fire behavior and EVAP / P index in fuel moisture. The consistency of the correlations between the various indices and the analyzed variables makes the methodology possible to be used in any place, facilitating the decision making in regions where records of occurrences of forest fires are absent or unreliable.
\end{abstract}

Keywords: Weather indices; Fine fuel moisture; Controlled burns.

\section{VARIÁVEIS DO COMPORTAMENTO DO FOGO E ÍNDICES DE PERIGO DE INCENDIOS FLORESTAIS}

\begin{abstract}
RESUMO - O objetivo deste estudo foi avaliar o desempenho de diferentes índices de perigo de incêndio (FWI, FMA, FMA+, Telicyn, Nesterov, P-EVAP e EVAP/P) levando em consideração as variáveis de comportamento do fogo e a suscetibilidade ao fogo expressa pela umidade do material combustivel. Para este propósito, queimas controladas foram realizadas em diferentes momentos e informações foram registradas em relação às condições meteorológicas, características do material combustível e variáveis do comportamento do fogo. Em geral, todos os indices apresentaram correlações significativas tanto com a umidade do material combustivel quanto com o comportamento do fogo. No entanto, em geral, uma maior correlação linear dos componentes do sistema canadense Fire Weather Index (FWI) foi observada na previsão do comportamento do fogo e do índice EVAP/P na umidade do combustivel. As correlações entre os vários índices e as variáveis analisadas tornam a metodologia passivel de ser utilizada em qualquer local, facilitando a tomada de decisão em regiões onde os registros de ocorrências de incêndios florestais estão ausentes ou não são confiáveis.
\end{abstract}

Palavras-Chave: Índices meteorológicos; Umidade do material combustível; Queimas controladas. 


\section{INTRODUCTION}

Fires result in dramatic changes in all types of forest ecosystems and have a big impact on both the biotic as well as the abiotic environments (Zaitsev et al., 2016). Among the three main factors (climate, fuels, and topography) that control the behavior of fires, climate is the most dynamic (Jolly et al., 2015). Climate affects the spread of fire indirectly through the influence on fuel moisture and directly through the direction of the wind (Rothermel, 1972; Finney, 2005) in such a way that the spread of fire is more intense when the weather is hot, dry, and windy (Holsinger et al., 2016).

Prior to this, many mathematical models, based on weather data, were developed to estimate the level of the risk of fire. These models has a numerical index that was translated into a level of alarm, which rise with the increased likelihood of fires (Hamadeh et al., 2017).

Finding the best universal index seems an impossible task due to the wide variety in the climatic and global factors that control the ignition (Pérez-Sánchez et al., 2017). Thus, it becomes necessary to compare the results of different indices to determine the most suitable index for each region (Schunk et al., 2017).

To compare the efficiency of risk indices, a wide range of methods is available in literature. In these cases, each day in the DataSet is generally classified as a "day of fire" or "day without fire" (Schunk et al., 2017). A linear model based on median percentile of results of occurrences and non-occurrences was used by Arpaci et al. (2013) to compare the indices in Austria. Torres et al. (2017) and Nunes et al. (2010) used the method known as Skill Score to compare the efficiency of indices in some regions of Brazil. The study of the values of percentiles according to the burned area, fires in a day, fires class was used by Viegas et al. (1999) to compare different regions of Europe. Others used the Mahalanobis distance (Crotteau et al., 2013; Pérez-Sánchez et al., 2017).

However, unfortunately, the techniques shown so far may not be universally applicable, as the instances of fires can be missing from the data or there may be only a few fires registered, to support a meaningful analyses (Schunk et al., 2017). In addition, several studies show that most occurrences of fires are of anthropic origin (Wastl et al., 2012; San-Miguel-Ayanz et al., 2013). Therefore, even though the danger is maximum, it does

Revista Árvore. 2018;42(3):e420306 not necessarily imply the presence of a fire, on the other hand on the days classified as minimum danger, due to anthropogenic influence, one can observe any occurrence. It is not enough that the factors directly associated with the occurrence of forest fires are favorable to the initial ignition and spread of fire, so that a fire occurs it is necessary the flame to initiate the combustion reaction. In other words, the association of only the values of the indices (or its child class), of the incidents, whether they took place or not, may not always portray the actual behavior of the events, because human intervention is not provided for in the calculations (Torres et al., 2014).

On the other hand, any significant fire danger index that uses weather data must show some form of correlation with the moisture content of the fuel, as this is the main factor of the ignition and spread of fire (Pyne et al., 1996). The fuel moisture determines the probability of ignition and spread of fires, so the estimate of the moisture content is the key factor in the behavior of fire (Pérez-Sánchez et al., 2017).

Therefore, besides the relationship between the predictive indices and fire behavior variables (intensity, speed, and height of the flame), the use of fuel moisture measurements when performing the evaluation of the danger index of fire is a justifiable approach. It represents a measure of the risk of ignition of fires (site-specific weather). This allows a greater variety of statistical analysis than the binary (days with fire vs. days without fire) and is independent of causes of human origin, which can be distributed unequally as far as space levels and risk of fire are concerned (Schunk et al., 2017).

With regard to the above, the objective of this study is to evaluate the performance of different fire danger indices, taking into account the variables of fire behavior and susceptibility to fire expressed by moisture in the combustible material, as the use of an index of danger that is very inefficient can lead to erroneous decisions in relation to the procedures for preventing and fighting forest fires, whereas, an index of reliable prediction can help the quantification and distribution of resources for prevention.

\section{MATERIALS AND METHODS}

Fuels with different characteristics respond differently to weather variations. In order to normalize

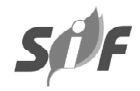


this variation, the present study was conducted on the campus of the Federal University of Viçosa (MG) $\left(20^{\circ} 46^{\prime} 23^{\prime} \mathrm{S}\right.$ and $\left.42^{\circ} 52^{\prime} 10^{\prime \prime} \mathrm{W}\right)$ in a clonal experiment on hybrids of Eucalyptus urophylla S. T. Blake and Eucalyptus grandis Hill ex Maiden, with an area of approximately 1 hectare, with an altitude average of $710 \mathrm{~m}, 10$ years of age, spacing $3 \times 3 \mathrm{~m}$, with $302^{\circ}$ (Northwest), and slope (10) uniform, generalizing the influences of relief. According to the data from the weather station at the University (INMET, 2017), it presents a climate type Cwb (Koppen), mesothermal rainy summers and dry winters, average temperature of $20.6^{\circ} \mathrm{C}$ and average annual rainfall of $1,229 \mathrm{~mm}$.

During the 80 days, set at random between 07/ $01 / 2016$ and $11 / 30 / 2016$, four instalments of controlled burns were carried out ( $2 \mathrm{~m}$ x $10 \mathrm{~m}$ ) per day ( 320 plots) at different periods: Period 1 starting at 09:00 hours; period 2 starting at 11:00 hours; period 3 beginning at 13:00 hours; and period 4 beginning at 15:00 hours. This was to seek to portray the time of year (winter and spring) and the time of greatest risk of forest fires (Torres et al., 2010).

In each of the plots, centered between the lines of planting, observations and measurements of the combustible material and weather variables were made, and during the fire, the fire behavior.

\subsection{Combustible material}

The characterization of the combustible material was carried out by gathering information on the quantity, moisture content, and thickness formed by deposition of material on the ground. These data were obtained through the inventory of material deposited on the floor of the forest. For this, $2,500 \mathrm{~cm}^{2}(50 \mathrm{~cm} \mathrm{x} 50 \mathrm{~cm})$ were allocated at random in each plot.

As for the type, the material was separated into four categories (Brown et al., 1982): Material with a diameter between 0 and $0.7 \mathrm{~cm}$ (here called CI), material with a diameter between 0.7 and $2.5 \mathrm{~cm}$ (IIC), material with a diameter between 2.5 and $7.6 \mathrm{~cm}$ (103), and material with larger diameter the $7.6 \mathrm{~cm}$ (CIV). The IC class was subdivided into three subclasses:

1. CI-V - organic material (grass).

2. CI-M - Miscellaneous-dead organic material, less than $0.7 \mathrm{~cm}$ thickness or diameter, composed mostly of Eucalyptus leaves, humus, grass, and the like.
3. CI-L - Woody material less than $0.7 \mathrm{~cm}$ thickness or diameter.

To test for humidity, the material collected was placed in an oven at $75^{\circ} \mathrm{C}$ until constant weight for determination of the weight of dry matter. The difference between the initial weight and weight of dry matter of the samples was estimated to be the fuel moisture content.

As for the amount, the combustible material was collected before and after each burn. The difference between the weight before (fuel) and after burning (residual fuel) provided the amount of material consumed by burning (one available or CD).

The average thickness of the layer of material deposited on the forest floor was measured in the samples during collection of combustible material with the use of a ruler, in the four corners of the template used, and similarly, after the burn, the thickness of the remaining material (residual fuel) was measured again. The difference between the thickness of the blanket before and after burning made it possible to estimate the variable "depth of burning" (PQ).

\subsection{Fire behavior variables}

At the time of the burning of each plot observations were made of the following fire behavior variables:

- Propagation Velocity (VP)-obtained visually, determining the time required for the firing line to go to distances of $1 \mathrm{~m}$, previously demarcated in each installment, in the sense of length $(10 \mathrm{~m})$

- Height of the flame (Hch)-visual estimate of average height achieved by the flames, every meter of advancement of the line of fire, with the aid of a ruler.

Through these observations, the following parameters were calculated:

- Fire Intensity (I)-estimated by Equation 1 proposed by Byram (1959):

$$
\mathrm{I}=\mathrm{H}^{*} \mathrm{~W}^{*} \mathrm{VP}
$$

where I is the intensity of the fire in $\mathrm{kw} \mathrm{m-1.}$ $\mathrm{s}-1, \mathrm{H}$ is the calorific value of damp material in kcal.kg-1, $\mathrm{W}$ is the weight of the fuel available in $\mathrm{kg} . \mathrm{m}-2$, and VP is the speed of the spread of fire in $\mathrm{s}-1$. 
The determination of the calorific value was performed in the Laboratory of Energy and Wood Paneling, in the Department of Forest Engineering, at the Federal University of Viçosa, using an adiabatic calorimeter of PARR, 1108, depending on the model NBR 8633 (ABNT, 1983). The estimate of the calorific value of the damp material (heat) was made from Equation 2 proposed by Countryman (1977):

$$
H w=H d\left[\frac{100-\frac{U}{7}}{100+U}\right]
$$

where, Hw is the calorific value of the wet matter in Kcal.kg-1, Hd is the calorific value of dry matter in Kcal.kg-1, and $\mathrm{U}$ is the moisture content by weight of dry matter, $\%$.

- Heat per unit area - defined by equation 3:

$$
\mathrm{Ca}=\frac{\mathrm{I}}{\mathrm{VP}}
$$

where, $\mathrm{Ca}$ is the heat released in kcal. ${ }^{-2}, \mathrm{I}$ is the intensity of the fire in $\mathrm{kw} \mathrm{m}^{-1} . \mathrm{s}^{-1}$, VP is the rate of spread of fire in $\mathrm{s}^{-1}$

- Lethal scorch height -defined by equation 4:

$$
\mathrm{Hcl}=\frac{3,94 \times \mathrm{I}^{\frac{7}{6}}}{\left(0,107 \times \mathrm{I}+\mathrm{v}^{3}\right)^{0,5}(60-\mathrm{t})}
$$

where, $\mathrm{Hcl}$ is the lethal scorch height in meters, $\mathrm{I}$ is the intensity of the fire in $\mathrm{kw} \mathrm{m}^{-1} \cdot \mathrm{s}^{-1}, \mathrm{v}$ is the wind speed $\mathrm{m} \cdot \mathrm{s}^{-1}, \mathrm{t}$ is the air temperature in ${ }^{\circ} \mathrm{C}$.

\subsection{Weather conditions}

During the period of the experiment, the weather conditions (precipitation and evaporation) were monitored continuously by the Meteorological Station of the Federal University of Viçosa, installed to $1 \mathrm{~km}$ away from the fire (with the same altitude and aspect of local). During the fire, meteorological observations were also made inside the settlement (temperature and relative humidity, wind speed, and direction), as also along the plots that were burned. The measurements were made at the beginning and end of every burn.

Revista Árvore. 2018;42(3):e420306

\subsection{Fire danger indices}

Seven fire danger indices were analyzed: Logarithmic Index of Telicyn; Cumulative indices of precipitationevaporation (P-EVAP); Division of evaporation by precipitation (EVAP/P); Nesterov index; Monte Alegre Formula (FMA); Monte Alegre formula Changed ( $\mathrm{FMA}^{+}$); and the Canadian Fire Weather index (FWI) Index (van Wagner, 1987). The choice of indices used was made from the function recurrence found in the literature and data acquisition facility, with the necessary calculations.

\section{Logarithmic Index of Telicyn}

Basic equation (Equation 5):

$$
I=\sum_{i=1}^{n} \log (t i-r i)
$$

where, $\mathrm{I}$ is the index of Telicyn, $\mathrm{t}$ is the air temperature in ${ }^{\circ} \mathrm{C}$, $\mathrm{r}$ is the dew point temperature in ${ }^{\circ} \mathrm{C}, \log$ is the logarithm in base 10

Whenever a precipitation is less than $2.5 \mathrm{~mm}$, the sum has to be left alone and calculations should start on the next day, or when the rains cease. On the day(s) of rain the index is equal to zero (Table 1).

\section{EVAP/P}

The EVAP/P index is also cumulative and relates the Division of evaporation by precipitation, both measures in $\mathrm{mm}$. For your calculation were used Table 1 restrictions.

\section{P-EVAP}

The cumulative index of P-EVAP lists the difference between precipitation $(\mathrm{P})$ and evaporation (EVAP). Both measure the daily precipitation in millimeters and also have some restrictions (Table 1).

\section{Nesterov Index}

Basic equation (Equation 6):

$$
G=\sum_{i=1}^{n} d i \times t i
$$

where, $\mathrm{G}$ is the index of Nesterov, $\mathrm{d}$ is the air saturation deficit in millibars, $\mathrm{t}$ is the air temperature in ${ }^{\circ} \mathrm{C}$. 
Table 1 - Restrictions of the indexes according the rain.

Tabela 1 - Restrições dos índices de acordo com a chuva.

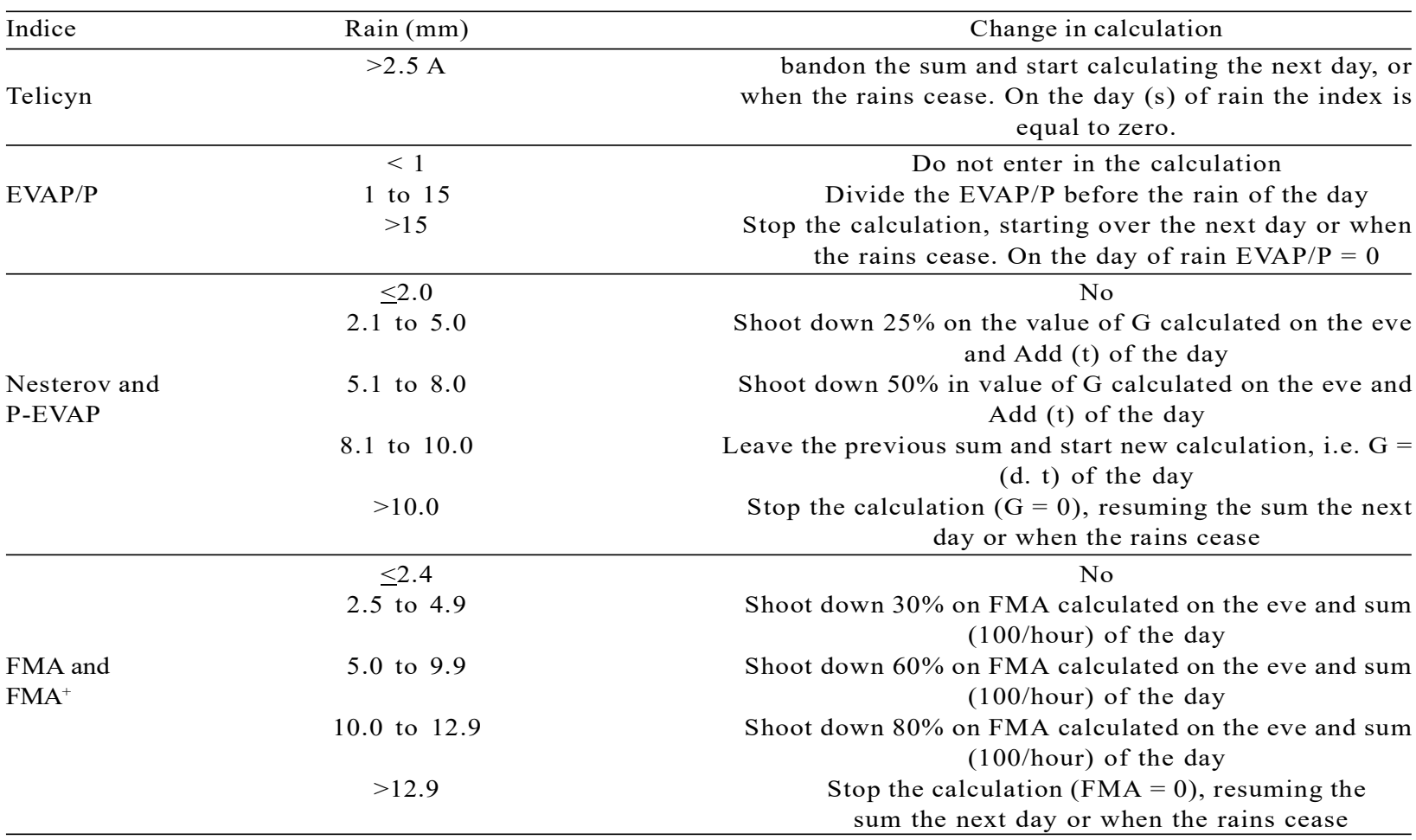

Source: Torres et al (2017)

The air saturation deficit for the time is equal to the difference between the maximum water vapor pressure and the actual water vapor pressure and can be calculated using the following expression (Equation 7):

$$
d=E \times\left(\frac{1-H}{100}\right)
$$

where, $d$ is the air saturation deficit in millibars, $\mathrm{E}$ is the maximum water vapor pressure in millibars, $\mathrm{H}$ is relative humidity in $\%$.

In the index of Nesterov, the continuity of the sum is limited by the occurrence of rainfall according to the Table 1 .

Monte Alegre formula

Basic equation (Equation 8):

$$
F M A=\sum_{i=1}^{n}\left(\frac{100}{H i}\right)
$$

where, FMA is the Monte Alegre formula, $\mathrm{H}$ is the relative humidity $(\%), \mathrm{n}$ is the number of days without rain.

The index introduces restrictions on the precipitation, as shown in Table 1 .

Monte Alegre Formula Changed

Basic equation (Equation 9):

$$
F M A^{+}=\sum_{i=1}^{n}\left(\frac{100}{H i}\right) \times e^{0,04 v}
$$

where, FMA+ is the Changed MonteAlegre Formula, $\mathrm{H}$ is the relative humidity $(\%), \mathrm{n}$ is the number of days without rain, $\mathrm{v}$ is the wind speed in $\mathrm{m} / \mathrm{s}$, and is the base of natural logarithms (2.718282).

Being cumulative, the index is also subject to the restrictions of precipitation, as shown in Table 1 .

Revista Árvore. 2018;42(3):e420306 


\section{Fire Weather Index}

The FWI System Index of the Canadian Forest Fire Hazard (CFFDRS) has six components: The first level of the FFMC - index of fine fuel moisture content; DMC - moisture content index of the organic layer; and DC - drought index representative of soil water deficit. All these are calculated from the weather data (temperature $\left({ }^{\circ} \mathrm{C}\right)$, relative humidity $(\%)$, and wind speed at $10 \mathrm{~m}$ height $(\mathrm{m} / \mathrm{s}))$.

In the intermediate level there are two indices related to the aspects of behavior or spread of fire: The ISIinitial spread index incorporates the index of fine fuel moisture content and the value of wind speed to produce a measure for the speed of the spread of fire on a flat terrain, as it should occur in the initial phase of a fire; and BUI - which integrates the two sub-indices DMC and DC to obtain an estimate of the proportion of available vegetation (medium and coarse particles) that will participate effectively in the spread. The end result of the system is a combination of the two groups, called danger index (FWI) that constitutes the data that more directly relates to the possibility of fires and their harmful effects. The six components of the FWI are calculated using a sequential set of tables (van Wagner, 1987), in this study we used the free software FWI CALCULATOR v. 10.2.1.

\section{Comparison of the efficiency of indices}

To determine which index is better correlated with each of the variables, the data were analyzed using the Pearson linear correlation $(p<0.05)$ in R ( R Core Team, 2017) with the Stats package. After creating the templates ( $\mathrm{x}$ moisture content of combustible material and indices $x$ fire behavior variables) the average of the correlations of each of the indices were calculated and the variables analyzed.

\section{RESULTS}

Only 1 sample presented material of the CIV class and only 6 presented material of class CIII, due to the lack of representativeness, they did not enter the analyzes.

In two days of the experiment the flames of period $1(09: 00 \mathrm{~h})$ became extinct before burning the entire parcel; in one day just the burning in the period 4 (15:00 h) managed to reach the end of the parcel; and in two days, in all the 4 periods, the fire managed to complete the course. These cases were entered in the analysis, however, the fire behavior variables received zero values for 'not burned' plots.

The correlations between the contents and the humidity of the combustible material and between indices and fire behavior variables can be observed in Tables 2 and 3 . All correlations were significant $(\mathrm{p}<0.05)$.

\section{DISCUSSION}

Few studies (beyond the traditional days with occurrences $x$ days without incidents), using other parameters to evaluate the performance of indices of fire hazard, may be found in the literature, including the study by Haines et al. (1983) that related the fire danger indices to the behavior of fire; and the studies of Aguado et al. (2007), Pereira et al. (2012), and Schunk et al. (2017), which related the indices of a fire hazard to the fine fuel moisture. Thus, the comparison of the efficiency of indices in other fields of study became monotonous, justifying the need for a greater number of studies, to get a better understanding of these correlations.

In general, all indices showed significant correlations with both the moisture of combustible material and the behavior of the fire. However, there was a greater efficiency of the EVAP/P and FWI indices on both fuel moisture prediction and fire behavior. EVAP/P seemed to better reflect the loss or gain of moisture from the combustible material, while the Canadian index had a higher correlation with the behavior of fire.

Table 2 - Pearson correlation coefficients for combustible moisture content and fire danger indices $(\mathrm{p}<0,05)$.

Tabela 2 - Correlação linear de Pearson entre os índices de perigo de incêndios e a umidade do material combustivel $(p<0,05)$.

\begin{tabular}{lcccccc}
\hline Indice & CI-M & CI-V & CI-L & CII & CT & mean \\
\hline EVAP/P & -0.77 & -0.85 & -0.76 & -0.83 & -0.83 & -0.81 \\
FWI & -0.78 & -0.82 & -0.72 & -0.81 & -0.83 & -0.79 \\
FMA+ & -0.73 & -0.82 & -0.71 & -0.80 & -0.80 & -0.77 \\
DMC & -0.72 & -0.77 & -0.79 & -0.79 & -0.79 & -0.77 \\
FMA & -0.72 & -0.69 & -0.68 & -0.71 & -0.76 & -0.71 \\
P-EVAP & -0.67 & -0.72 & -0.61 & -0.69 & -0.73 & -0.68 \\
ISI & -0.69 & -0.55 & -0.72 & -0.61 & -0.65 & -0.64 \\
FFMC & -0.64 & -0.43 & -0.81 & -0.51 & -0.61 & -0.60 \\
BUI & 0.62 & 0.54 & 0.57 & 0.56 & 0.65 & 0.59 \\
Nesterov & -0.57 & -0.60 & -0.51 & -0.57 & -0.62 & -0.57 \\
Telicyn & -0.53 & -0.49 & -0.46 & -0.48 & -0.56 & -0.50 \\
DC & -0.37 & -0.45 & -0.46 & -0.44 & -0.36 & -0.42 \\
\hline
\end{tabular}

Revista Árvore. 2018;42(3):e420306 
Table 3 - Pearson correlation coefficients for fire behavior variables and fire danger indices $(\mathrm{p}<0,05)$.

Tabela 3 - Correlação linear de Pearson entre os índices de perigo de incêndios e as variáveis do comportamento do fogo $(p<0,05)$.

\begin{tabular}{lcccccccc}
\hline Indice & PQ & VP & Hch & CD & I & CA & 0.74 & 0.76 \\
FWI & 0.68 & 0.78 & 0.87 & 0.73 & 0.74 & 0.76 \\
EVAP/P & 0.62 & 0.85 & 0.85 & 0.67 & 0.72 & 0.64 & 0.75 \\
FMA+ & 0.52 & 0.52 & 0.74 & 0.67 & 0.69 & 0.74 & 0.71 \\
ISI & 0.59 & 0.89 & 0.66 & 0.57 & 0.64 & 0.75 & 0.46 \\
P-EVAP & 0.62 & 0.51 & 0.73 & 0.66 & 0.61 & 0.73 & 0.65 \\
DMC & 0.56 & 0.46 & 0.69 & 0.6 & 0.58 & 0.68 & 0.59 \\
FFMC & 0.65 & 0.59 & 0.63 & 0.62 & 0.47 & 0.56 & 0.50 \\
BUI & -0.40 & -0.46 & -0.64 & -0.57 & -0.63 & 0.63 & -0.63 \\
FMA & 0.44 & 0.4 & 0.63 & 0.54 & 0.54 & 0.62 & 0.57 \\
Nesterov & 0.33 & 0.37 & 0.57 & 0.49 & 0.53 & 0.56 & 0.57 \\
Telicyn & 0.29 & 0.37 & 0.52 & 0.44 & 0.49 & 0.49 & 0.53 \\
DC & 0.32 & 0.37 & 0.36 & 0.48 & 0.46 & 0.47 & 0.48 \\
\hline
\end{tabular}

The separation of the combustible materials in various classes allowed for the understanding of the different responses of the contents analyzed. The dead material (C1-M) showed the highest correlation with FWI, which represents the intensity of the fire, similar to studies of Schunk et al. (2017) in Germany. The FFMC (fine fuel moisture content) fulfilled the role in correlation with the CI-L, expected result due to the characteristics of the calculation (van Wagner, 1987). On the other hand, DC was the least correlated with moisture from the fuel (and with the fire behavior variables), which was expected, due to the slow response of this component to the variation in weather conditions (Schunk et al., 2017). A feature also rates the Brazilian index FMA+ as the third best placed with regard to the fuel moisture prediction and in relation to the behavior of the fire and the wind factor in the calculation. What differentiates it from the fellow Brazilian FMA is, in this there is an indication that the meteorological element influences the drying of combustible material.

Analyzing the efficiency of indices by taking into account the behavior of the fire, the depth of the burns showed the highest correlation with the FWI and FFMC, which was expected, as it was related to the moisture of the fine material and the intensity of the fire. The rate of spread correlated more with the initial spread index of the fire (ISI), which was also within expectations, because this index expressed the joint effect of wind and moisture from the combustible material. As FWI combines ISI with BUI, a greater correlation with the height of the flame, fire intensity, and thus lethal height, was also expected. Therefore, it was considered the best index for prediction of fire behavior variables in the study area.
The traditional approach that compares the indices with the occurrence or non-occurance of fires, also shows the greater efficiency of the FWI and FMA+ indices in relation to the percentage of occurrence during the days with risk (95\% and $93.7 \%$ ) and without risk (5.1\% and 6.4\%) for the area of study, on the other hand, it presents the Telicyn index as the most efficient taking into account the sources of heat obtained by satellites (Torres et al., 2017). In Juiz de Fora, in the $160 \mathrm{~km}$ studied, the EVAP/P index was the most efficient (Torres and Ribeiro, 2008).

In the State of São Paulo, the FWI was highlighted as the most efficient index, followed by Telicyn, Nesterov, and finally the FMA (Torres et al., 2017). In addition, a study conducted in the State of Minas Gerais, municipality of Coronel Fabriciano, $138 \mathrm{~km}$ off Viçosa, identified the EVAP/P indices as the most efficient (Torres et al., 2017). Holsten et al. (2013) reported that for Germany, the Canadian index was the most effective, whereas, the Nesterov was the lowest efficiency.

Correlations between fire risk indices and variables analyzed show that this methodology can be used anywhere. This facilitates decision-making by increasing confidence in the results and can be used in areas without records or reliable data on forest fires. The literature also indicates the possibility of automatic measurements of humidity of the fine material, which saves time in obtaining the results (Schunk et al., 2017).

\section{CONCLUSIONS}

The components of the Canadian system of prediction of forest fires and the Brazilian EVAP/P were

Revista Árvore. 2018;42(3):e420306 
the largest linear correlations, with the variables analyzed, whereas, the Russians Nesterov and Telicyn were the least correlated. The results presented here, as well as the very definition of the index, correlated more with the variables studied, and indicated that the approach to the analysis of the efficiency of indices in relation to moisture of combustible material and fire behavior variables is efficient. The consistency of correlations between the various indices and analyzed variables makes the methodology fit enough to be used in any location, and this facilitates decision-making, as well as increases one's confidence in the results, allowing its use in regions where records of fire occurrences are absent or not trustworthy.

\section{REFERENCES}

Aguado I, Chuvieco E, Borén R, Nieto H. Estimation of dead fuel moisture content from meteorological data in Mediterranean areas. Applications in fire danger assessment. International Journal of Wildland Fire. 2007;16:390-7.

Arpaci A, Eastaugh CS, Vacik H. Selecting the best performing fire weather indices for Austrian ecoregions. Theoretical and Applied Climatology. 2013;114:393-406. doi:10.1007/s00704-013-0839-7.

Associação Brasileira de Normas Técnicas - ABNT -. Normas Técnicas NBR 8633. Brasília, DF: 1983.

Brown J, Bevins C. Surface fuel loadings and prediced fire behavior for vegetation types in the northern Rocky Mountains. Research Note INT358. Ogden: USDA Forest Service; 1986.

Byram GM. Combustion of forest fuels. In: Davis KP, editor. Forest fire: Control and use. New York: McGraw-Hill; 1959.

Countryman CM. The nature of heat. Portland: Pacific Southwest Forest and Range Experiment Station; 1977.

Crotteau JS, Morgan Varner J, Ritchie MW. Postfire regeneration across a fire severity gradient in the southern Cascades. Forest Ecology and Management. 2013;287:103-12.

Finney MA. The challenge of quantitative risk analysis for wildland fire. Forest Ecology and Management. 2005;211:97-108.

Revista Árvore. 2018;42(3):e420306
Hamadeh N, Karouni A, Daya B, Chauvet P. Using correlative data analysis to develop weather index that estimates the risk of forest fires in Lebanon \& Mediterranean: Assessment versus prevalent meteorological indices. Case Studies in Fire Safety. 2016:1-15.

Haines DA, Main WA, Frost JS, Simard AJ. Firedanger rating and wildfire occurrence in the northeastern United States. Forest science. 1983;29:679-96.

Holsinger L, Parks SA, Miller C. Forest ecology and management weather, fuels, and topography impede wildland fire spread in western US landscapes. Forest Ecology and Management. 2016;380:59-69.

Holsten A, Dominic AR, Costa L, Kropp JP. Evaluation of the performance of meteorological forest fire indices for German federal states. Forest Ecology and Management. 2013;287:123-131.

Instituto Nacional de Meteorologia - INMET -. Banco de Dados Meteorológicos para Ensino e Pesquisa - BDMEP -. Ministério da Agricultura, Pecuária e Abastecimento. Brasilia, DF: 2017. [acesado em: 19 maio, 2017]. Disponível em: http:/ /www.inmet.gov.br/portal/index.php?r=bdmep/ bdmep.

Jolly WM, Cochrane MA, Freeborn PH, Holden ZA, Brown TJ, Williamson GJ, et al. Climateinduced variations in global wildfire danger from 1979 to 2013. Nature Communications. 2015;6:7537.

Nunes JRS, Fier ISN, Soares RV, Batista AC. Desempenho da Fórmula de Monte Alegre (FMA) e da Fórmula de Monte Alegre alterada (FMA +) no Distrito Florestal de Monte Alegre. Floresta. 2010;40:319-26.

Pereira JF, Batista AC, Soares RV. Forest fuel moisture variation in terms of forest fire danger index. Cerne 2012;18:371-6.

Pérez-Sánchez J, Senent-Aparicio J, DíazPalmero JM, Cabezas-Cerezo JD. A comparative study of fire weather indices in a semiarid south-eastern Europe region. Case of study: Murcia (Spain). Science of the Total Environment. 2017;590-1:761-74.

\section{Revista Árvore. 2018,42(3):e420306}


Pyne SK, Andrews PL, Laven RD. Introduction to Wildland Fire. New York: John Wiley \& Sons; 1996.

R Core Team. R: A language and environment for statistical computing. Vienna: R Foundation for Statistical Computing; 2017.

Rothermel RC. A mathematical model for predicting fire spread in wildland fuels. Ogden: USDA Forest Service; 1972. (Research Paper INT-115)

San-Miguel-Ayanz J, Schulte E, Schmuck G, Camia A. The European forest fire information system in the context of environmental policies of the European Union. Forest Policy and Economics. 2013;29:19-25.

Schunk C, Wastl C, Leuchner M, Menzel A. Agricultural and forest meteorology fine fuel moisture for site- and species-specific fire danger assessment in comparison to fire danger indices. Agricultural and Forest Meteorology. 2017;234-235:31-47.

Torres FTP, Lima GS, Martins SV, Valverde SR. Analysis of efficiency of fire danger indices in forest fire prediction. Revista Árvore. 2017;41:1-10.

Torres FTP, Ribeiro GA, Martins SV, Lima GS. Determinação do período mais propício às ocorrências de incêndios em vegetação na área urbana de Juiz de Fora, MG. Revista Árvore 2010;34(2):297-303.

Torres FTP, Ribeiro GA, Martins SV, Lima GS. Mapeamento da suscetibilidade a ocorrências de incêndios em vegetação na área urbana de UbáMG. Revista Árvore. 2014;38:811-7.

Wastl C, Schunk C, Leuchner M, Pezzatti GB, Menzel A. Recent climate change: Long-term trends in meteorological forest fire danger in the Alps. Agricultural and Forest Meteorology. 2012;162-163:1-13.

van Wagner CE. Development and structure of the canadian forest fire weather index system.

Ontario: Canadian Forest Service; 1987. (Forestry Technical Report, 35)

Viegas DX, Bovio G, Ferreira A, Nosenzo A, Sol B. Comparative study of various methods of fire danger evaluation in southern Europe.

International Journal of Wildland Fire. 1999;9:235.

Zaitsev AS, Gongalsky KB, Malmström A, Persson $\mathrm{T}$, Bengtsson $\mathrm{J}$. Why are forest fires generally neglected in soil fauna research? A mini-review. Applied Soil Ecology. 2016;98:261-71. 